\title{
Abbreviations and Literature
}

Abbreviations, which have been used to a minimum, can be found at http://www.rla.badw.de/ reallexikon/abkuerzungslisten.html.

\section{Additional Abbreviations}

DJBA

Sokoloff, M. 2002. A Dictionary of Jewish Babylonian Aramaic of the Talmudic and Geonic Periods. Ramat-Gan, Israel: Bar Ilan University Press; Baltimore: Johns Hopkins University Press.

Jastrow Dictionary Jastrow, M. 1950. A Dictionary of the Targumim, the Talmud Babli and the Yerushalmi, and the Midrashic Literature. New York: Pardes Publishing House.

Mandaic Dictionary Drower, E.S. and R. Macuch. 1963. A Mandaic Dictionary. Oxford: Clarendon Press.

SEAL

http://www.seal.uni-leipzig.de.

UH

Udug-hul incantations, see Geller 2016 below.

\section{Literature}

Abrahami $2014=$ P. Abrahami. Wool in the Nuzi Texts. In Wool Economy in the Ancient Near East and the Aegean. From the Beginnings of Sheep Husbandry to Institutional Textile Industry, eds. C. Breniquet and C. Michel. Ancient Textiles Series 17. Oxford and Philadelphia: Oxbow Books: 283309.

Abusch $2015=\mathrm{T}$. Abusch, The Witchcraft Series Maqlû. Atlanta, Georgia: SBL Press.

Abusch 2016 = T. Abusch. The Magical Ceremony Maqlû: A Critical Edition. Ancient Magic and Divination 10. Leiden and Boston: Brill.

Abusch and Schwemer $2011=$ T. Abusch, T. and D. Schwemer. Corpus of Mesopotamian Anti-Witchcraft Rituals, Volume 1. Ancient Magic and Divination 8/1. Leiden and Boston: Brill.

Abusch, Schwemer, Luuko, Van Buylaere $2016=$ T. Abusch, D. Schwemer, M. Luukko, and G. Van Buylaere. Corpus of Mesopotamian Anti-Witchcraft Rituals, Volume 2. Ancient Magic and Divination 8/2. Leiden and Boston: Brill.

Ambos $2013=$ C. Ambos. Der König im Gefängnis und das Neujahrsfest im Herbst: Mechanismen der Legitimation des babylonischen Herrschers im 1. Jahrtausend v. Chr. und ihre Geschichte. Dresden: Islet.

Annus $2019=$ A. Annus. The Spiritual Dimensions of Healing Rituals in Ancient Mesopotamia. Journal of Religion and Health, https://doi.org/10.1007/s10943-019-00964-x.

Arkhipov $2009=1$. Arkhipov. L'usage médical du plomb à Mari. Le Journal des Médecines Cunéiformes 13: 48.

Arnaud $1987=$ D. Arnaud. Textes de la bibliothèque, transcriptions et traductions. Recherches au pays d'aštata. EMAR 6/4. Paris: Editions Recherche sur les Civilisations.

Arnaud 2007 = D. Arnaud. Corpus des textes de bibliothèque de Ras Shamra-Ougarit (1936-2000): en sumérien, babylonien et assyrien. Aula Orientalis. Supplementa 23. Sabadell: Ausa. 
Arnott $2002=$ R. Arnott. Disease and Medicine in Hittite Asia Minor. In The Archaeology of medicine : papers given at a session of the annual conference of the Theoretical Archaeology Group held at the University of Birmingham on 20 December 1998, ed. R. Arnott. BAR international series 1046. Oxford: Archaeopress: 41-52.

Arnott $2004=$ R. Arnott, Minoan and Mycenaean Medicine and its Near Eastern Contacts. In Magic and Rationality in Ancient Near Eastern and Graeco-Roman Medicine, eds. H.F.J. Horstmanshoff and M. Stol. Studies in Ancient Medicine 27. Leiden-Boston: Brill: 153-173.

Attia 2015 = A. Attia. Traduction et commentaires des trois premières tablettes de la série IGI. Le Journal des Médecines Cunéiformes 25: 1-120.

Attia and Buisson 2003 = A. Attia and G. Buisson. Si le crâne d'un homme contient de la chaleur, deuxième tablette. Le Journal des Médecines Cunéiformes 1: 1-24.

Attia and Buisson $2007=\mathrm{A}$. Attia and G. Buisson. $\mathrm{K} 2392$, un nouveau joint pour UGU 2. Le Journal des Médecines Cunéiformes 9: 47-48.

Attia and Buisson $2012=$ A. Attia and G. Buisson. BAM 1 et consorts en transcription. Le Journal des Médecines Cunéiformes 19: 22-51.

Attinger $2008=$ P. Attinger. La médecine mésopotamienne. Le Journal des Médecines Cunéiformes 1112: $1-96$.

Bácskay 2015 = A. Bácskay. Magical-medical prescriptions against fever: an edition of BM 42272. Le Journal des Médecines Cunéiformes 26: 1-32.

Bácskay 2018a = A. Bácskay. Therapeutic Prescriptions against Fever in Ancient Mesopotamia. Alter Orient und Altes Testament 447. Münster: Ugarit.

Bácskay 2018 b = A. Bácskay. 'Seize a frog!' The use of the frog in medical and magical texts. Le Journal des Médecines Cunéiformes 32: 1-16.

Bácskay 2018c = A. Bácskay. The 34th Extract of the UGU Series from Babylon: An Edition of the Tablet BM 35512. In Mesopotamian Medicine and Magic. Studies in Honor of Markham J. Geller, ed. S.V. Panayotov and L. Vacín, with the assistance of Gene Trabich. Ancient Magic and Divination 14. Leiden and Boston: Brill: 93-115.

Bácskay and Simkó 2017 = A. Bácskay, and K. Simkó. Edition of BAM 494. The fifth tablet of UGU or a compilation of recipes against the skin diseases of the head. Le Journal des Médecines Cunéiformes 27: 1-71.

Bagg $2000=$ A.M. Bagg. Assyrische Wasserbauten: Landwirtschaftliche Wasserbauten im Kernland Assyriens zwischen der 2. Hälfte des 2. und der 1. Hälfte des 1. Jahrtausends v. Chr. Baghdader Forschungen 24. Mainz am Rhein: Von Zabern.

Bauer $2007=$ J. Bauer. Review of: van Dijk and Geller 2003. Ur III Incantations from the Frau Professor Hilprecht-Collection, Jena. Bibliotheca Orientalis 64: 175-179.

Beaulieu 1994 = P.-A. Beaulieu. Late Babylonian Texts in the Nies Babylonian Collection. Catalogue of the Babylonian Collections at Yale 1. Bethesda: CDL Press.

Beck 2015 = S. Beck. Sāmānu as a Human Disease. Journal des Médecines Cunéiformes 26: 33-46.

Besnier, Boutrolle, Chanut and Hawley $2015=$ M.-F. Besnier, P. Boutrolle, C. Chanut and R. Hawley. On the Junipers of Ugarit. Part 2: The word diprānu and the genus junipers. Orient \& Méditerranée Archéologie 16: 81-156.

Biggs $1974=$ R. Biggs. A Babylonian Extispicy Text Concerning Holes. Journal of Near Eastern Studies 33: 351-356.

Borger $1967=$ R. Borger. Handbuch der Keilschriftliteratur. Band I, Repertorium der sumerischen und akkadischen Texte. Berlin: Walter de Gruyter.

Borger $1975=$ R. Borger. Handbuch der Keilschriftliteratur Band II, Supplement zu Band I Anhang: zur Kuyunjik-Sammlung. Berlin: Walter de Gruyter. 
Borger $1991=$ R. Borger. Ein Brief Sîn-idinnams von Larsa an den Sonnengott sowie Bemerkungen über "Joins" und das "Joinen". Nachrichten von der Akademie der Wissenschaften in Göttingen. I. Philologisch-Historische Klasse 1991, Nr. 2. Göttingen : Vandenhoeck and Ruprecht.

Borger $2010=$ R. Borger. Mesopotamisches Zeichenlexikon. Zweite, revidierte und aktualisierte Auflage. Alter Orient und Altes Testament 305, 2. Auflage. Münster: Ugarit.

Böck $2000=$ B. Böck. Die babylonisch-assyrische Morphoskopie. Archiv für Orientforschung, Beiheft 27. Wien: Horn, Austria Berger.

Böck $2003=$ B. Böck. Hauterscheinungen in altmesopotamischer Divination und Medizin Teil 1: Das kurāru-Mal. Aula Orientalis 21: 161-184.

Böck $2004=$ B. Böck. Anmerkungen zu zwei medizinischen Texten aus Assur. Nouvelles Assyriologiques Brèves et Utilitaires 2004-2: no. 42.

Böck 2007 = B. Böck. Das Handbuch Muššu’u “Einreibung”. Eine Serie Sumerischer und Akkadischer Beschwörungen aus dem 1. Jt. vor Chr. Biblioteca del Próximo Oriente Antiguo 3. Madrid: Consejo Superior de Investigaciones Científicas.

Böck 2009 = B. Böck. On Medical Technology in Ancient Mesopotamia. In Advances in Mesopotamian Medicine from Hammurabi to Hippocrates. Proceedings of the International Conference "Oeil malade et mauvais oeil," Collège de France, Paris, 23rd June 2006, eds. A. Attia and G. Buisson. Cuneiform Monographs 37. Leiden-Boston: Brill: 105-128.

Böck $2014=$ B. Böck. The Healing Goddess Gula. Towards an Understanding of Ancient Babylonian Medicine. Culture and History of the Ancient Near East 67. Leiden-Boston: Brill.

Bourguignon 2012 = A. Bourguignon. Les emprunts sémitiques en grec ancien. Étude méthodologique et exemples mycéniens. Thèse présentée en vue de l'obtention du grade académique de Docteur en Langues et lettres, sous la direction de Monsieur Philippe Talon. Université Libre de Bruxelles.

Brunke $2011=$ H. Brunke. Essen in Sumer: Metrologie, Herstellung und Terminologie nach Zeugnis der Ur III-zeitlichen Wirtschaftsurkunden. Geschichtswissenschaften 26. München: Herbert Utz Verlag.

Budge 1913 = E.A.W. Budge. Syrian Anatomy, Pathology and Therapeutics or "The Book of Medicines": The Syriac text, edited from a rare manuscript, with an English Translation, etc. Volume 2, English Translation and Index. London et al.: Humphrey Milford-Oxford University Press.

Cadelli 2000 = D. Cadelli. Recherche sur la Médecine Mésopotamienne: La Série šumma amêlu suâlam maruṣ. Doctorat de l'Université de Paris I Panthéon Sorbonne.

Cadelli 2001, see Stol, Cadelli, and Milano 2001.

Caplice 1967 = R. Caplice. Namburbi Texts in the British Museum III. Orientalia Nova Series 36: 273298.

Chalendar $2018=$ V. Chalendar. Éléments de pharmacopée mésopotamienne : retour sur l'ingrédient rikibtu. Le Journal des Médecines Cunéiformes 32: 24-55.

Civil $1984=$ M. Civil. 'On Some Terms for "Bat” in Mesopotamia.' Aula Orientalis 2: 5-9.

Civil $1986=$ M. Civil. Materials for the Sumerian Lexicon: Supplementary Series 1. Roma: Pontificium Institutum Biblicum.

Civil $1996=$ M. Civil. HAR-ra $=$ hubullu: Tablet X dug = karpatu. In Sallaberger, W. Der babylonische Töpfer und seine Gefäße nach Urkunden altsumerischer bis altbabylonischer Zeit sowie lexikalischen und literarischen Zeugnissen. Mesopotamian History and Environment, Memoirs 3. Ghent: University of Ghent: 129-160.

Clancier 2009 = P. Clancier. Les bibliothèques en Babylonie dans la deuxième moitié du ler millénaire av. J.-C. Alter Orient und Altes Testament 363. Münster: Ugarit.

Cohen and Llop $2017=$ Y. Cohen and J. Llop. A Private Middle Assyrian Letter Sent by Pilta-ādur to Nabbānu (with an Aphorism drawn from the World of Medicine). Zeitschrift für Assyriologie und Vorderasiatische Archäologie 107: 105-110.

Collins 1999 = T.J. Collins. Natural Illness in Babylonian Medical Incantations. PhD. Dissertation. Chicago: University of Chicago. 
Couto-Ferreira $2009=$ E. Couto-Ferreira. Etnoanatomía y partonomía del cuerpo humano en sumerio y acadio. El léxico Ugu-mu. Tesi doctoral, Universitat Pompeu Fabra. Departament d'Humanitats.

Couto-Ferreira $2013=$ E. Couto-Ferreira. The Circulation of Medical Practitioners in The Ancient Near East: The Mesopotamian Perspective. In Mediterráneos: An Interdisciplinary Approach to the Cultures of the Mediterranean Sea, eds. Sergio Carro Martín et al. Newcastle upon Tyne: Cambridge Scholars Publishing: 401-416.

Craik $2005=$ E. Craik. The Hippocratic Treatise peri opsios (de vedendi acie, On the Origan of Sight). In Hippocrates in Context: Papers Read at the XIth International Hippocrates Colloquium (University of Newcastle upon Tyne, 27-31 August 2002), ed. P. van der Eijk. Leiden: Brill: 191-207.

Craik 2015 = E. Craik. The 'Hippocratic' Corpus: Content and Context. Milton Park, Abingdon, Oxon; New York, NY: Routledge.

Coughlin $2016=\mathrm{S}$. Coughlin. Physiology of Perception. In The Soul is an Octopus: ancient ideas of life and the body, ed. U. Kornmeier. Berlin: Berliner Medizinhistorisches Museum der Charité, Berlin: Excellence Cluster Topoi: 52-62.

Cunningham 1997 = G. Cunningham. Deliver me from evil. Mesopotamian incantations 2500-1500 BC. Studia Pohl, Series maior 17. Roma: Pontifcio Istituto Biblico.

Dalley and Postgate $1984=$ S. Dalley and J.N. Postgate. The tablets from Fort Shalmaneser. Cuneiform Texts from Nimrud 3. London: British School of Archaeology in Iraq.

del Olmo Lete 2007 = G. del Olmo Lete. The Biconsonantal Semitic Lexicon. The Series /B-X-/*. Aula Orientalis 25: 201-235.

del Olmo Lete $2014=\mathrm{G}$. del Olmo Lete. Incantations and Anti-Witchcraft Texts from Ugarit. With a contribution by Ignacio Márquez Rowe. Studies in Ancient Near Eastern Records 4. Boston and Berlin. Walter de Gruyter.

Deller $1985=$ K. Deller. SAG.DU UR.MAH, >>Löwenkopfsitula, Löwenkopfbecher<<. Baghdader Mitteilungen 16: 327-346.

Drower 1946 = E.S. Drower. A Phylactery for Rue (an Invocation of the Personified Herb). Orientalia Nova Series 15: 324-346.

Durant $2006=\mathrm{J}$. -M. Durand. Remarques sur le vocabulaire de quelques parties du corps. In Médecine et médecins au Proche-Orient ancient. Actes du Colloque International organisé à Lyon les 8 et 9 novembre 2002, Maison de l'Orient et de la Méditerranée, eds. L. Battini and P. Villard. BAR International Series 1528. Oxford: Oxford Hedges: 65-72.

Edel 1976 = E. Edel. Ägyptische Ärzte und ägyptische Medizin am hethitischen Königshof. Neue Funde von Keilschriftbriefen Ramses' II. aus Boğazköy. Rheinisch-Westfalischen Akademie der Wissenschaften G 205. Opladen: Westdeutscher Verlag.

Eypper 2019 = S. Choukassizian. Kasûu( $\left.{ }^{(} \mathrm{GAZI}{ }^{\mathrm{SAR}}\right)$ Revisited. Journal des Médecines Cunéiformes 33: 3549.

Falkenstein 1931 = A. Falkenstein. Die Haupttypen der sumerischen Beschwörung. Leipziger semitistische Studien, n. F., Bd. 1. Leipzig.

Farber 1974 = W. Farber. Saghulhaza mukīl rēš lemutti. Zeitschrift für Assyriologie und Vorderasiatische Archäologie 64: 87-95.

Farber $1981==$ W. Farber. Zur älteren akkadischen Beschwörungsliteratur. Zeitschrift für Assyriologie und Vorderasiatische Archäologie 71: 51-72.

Farber 1982 = W. Farber. Review of Franz Köcher, Die babylonisch-assyrische Medizin in Texten und Untersuchungen, Bd. V und VI. Bibliotheca Orientalis 39: 592-599.

Farber 1989 = W. Farber. Schlaf, Kindchen, Schlaf! Mesopotamische Baby-Beschwörungen und -Rituale. Mesopotamian Civilizations 2. Winona Lake: Eisenbrauns.

Farber 1990 = W. Farber. Mannam lušpur ana Enkidu: Some New Thoughts about an Old Motif. Journal of Near Eastern Studies 49: 299-321. 
Farber 1998 = W. Farber. māra/āt Anim oder: Des Anu Töchterlein. In Singular und Plural, Text und Bild. In Festschrift für Rykle Borger zu seinem 65. Geburtstag am 24. Mai 1994: tikip santakki mala bašmu, ed. S. Maul. Groningen: Styx Publications: 59-69.

Farber 2014 = W. Farber. Lamaštu. An Edition of the Canonical Series of Lamaštu Incantations and Rituals and Related Texts from the Second and First Millennia B.C. Mesopotamian Civilizations 17. Winona Lake, Indiana: Eisenbrauns.

Feder $2016=$ Y. Feder. Defilement, Disgust, and Disease: The Experiential Basis of Hittite and Akkadian Terms for Impurity. Journal of the American Oriental Society 136: 99-116.

Feliu 2003 = L. Feliu. The God Dagan in Bronze Age Syria. Culture and History of the Ancient Near East 19. Leiden and Boston: Brill.

Fincke 1998 = J.C. Fincke. SpTU III Nr. 85 joint zu SpTU II Nr. 22. Nouvelles Assyriologiques Brèves et Utilitaires 1988/26.

Fincke $2000=$ J.C. Fincke . Augenleiden nach keilschriftlichen Quellen. Untersuchungen zur altorientalischen Medizin. Würzburger medizinhistorische Forschungen 70. Würzburg: Königshausen und Neumann.

Fincke 2003/04 = J.C. Fincke. The Babylonian Texts of Nineveh. Report on the British Museum's Ashurbanipal Library Project. Archiv für Orientforschung 50: 111-149.

Fincke 2007 = J.C. Fincke. Omina, die göttliche "Gesetze" der Divination. Jaarbericht Ex Oriente Lux 40: 131-147.

Fincke $2009=$ J.C. Fincke. Cuneiform Tablets on Eye Diseases: Babylonian Sources in Relation to the Series DIŠ NA IGI"-šú GIG. In Advances in Mesopotamian Medicine from Hammurabi to Hippocrates. Proceedings of the International Conference "Oeil malade et mauvais oeil," Collège de France, Paris, 23rd June 2006, eds. A. Attia and G. Buisson. Cuneiform Monographs 37. Leiden and Boston: Brill: $79-104$.

Fincke 2010 = J.C. Fincke. KUB 4, 50: Ein medizinischer Text über Augenkrankheiten aus Hattuša. Nouvelles Assyriologiques Brèves et Utilitaires 2010/12.

Fincke $2011=$ J.C. Fincke. Spezialisierung und Differenzierung im Bereich der altorientalischen Medizin. Die Dermatologie am Beispiel der Symptome simmū matqūtu, kalmātu (matuqtu), kibšu, kișșatu und gurištu. In The Empirical Dimension of Ancient Near Eastern Studies: Die empirische Dimension altorientalischer Forschungen, eds. G.J. Selz and K. Wagensonner. Wien: Lit: 159-208.

Finkel $1976=$ I.L. Finkel. HUL.BA.ZI.ZI: Ancient Mesopotamian Exorcistic Incantations. Ph. D. Faculty of Arts, University of Birmingham.

Finkel 1991 = I.L. Finkel. Muššu'u, Qutāru, and the Scribe Tanittu-Bēl. Aula Orientalis 9 (Fs. M. Civil): 91-104.

Finkel $1998=$ I.L. Finkel. A Study in Scarlet: Incantations against Samana. In Festschrift für Rykle Borger zu seinem 65. Geburtstag am 24. Mai 1994: tikip santakki mala bašmu, ed. S. Maul. Cuneiform Monographs 10. Groningen: Styx Publications: 71-106.

Finkel 1999 = I.L. Finkel. On Some Dog, Snake and Scorpion Incantations. In Mesopotamian Magic, Textual, Historical, and Interpretative Perspectives, eds. T. Abusch and K. van der Toorn. Ancient Magic and Divination 1. Groningen: Styx Publications: 213-250.

Finkel $2004=$ I.L. Finkel. Old Babylonian medicine at Ur: letter aux éditeurs. Le Journal des Médecines Cunéiformes 4: 26.

Finkel $2007=$ I.L. Finkel. On the Rules for the Royal Game of Ur. In Ancient Board games in perspective: papers from the 1990 British Museum colloquium, with additional contributions, ed. I.L. Finkel. London: British Museum Press: 16-32.

Finkel $2018=$ I.L. Finkel. On Three Tablet Inventories. In Assyrian and Babylonian Scholarly Text Catalogues: Medicine, Magic and Divination, ed. U. Steinert. Die babylonisch-assyrische Medizin in Texten und Untersuchungen 9. Berlin and Boston: Walter de Gruyter: 25-41. 
Finkel and Reade $2002=$ I.L. Finkel and J.E. Reade. 2002. On Some Inscribed Babylonian Alabastra. Journal of the Royal Asiatic Society of Great Britain \& Ireland 12: 31-46.

Forbes $1950=$ R.J. Forbes. Metallurgy in Antiquity: A Notebook for Archaeologists and Technologists. Leiden: Brill.

Foster 2005 = B.R. Foster. Before the Muses. An Anthology of Akkadian Literature. Third Edition. Bethesda: CDL Press.

Frankfurter $2001=$ D. Frankfurter. Narrating power: the theory and practice of the magical historiola in ritual spells. In Ancient Magic and Ritual Power, (eds.) M. Meyer and P. Mirecki. Religions in the Graeco-Roman world 129. Leiden-Boston: Brill: 457-476.

Freedman 1998 = S. Moren Freedman. If a city is set on a height: the Akkadian omen series Šumma alu ina mèlê šakin. Vol. 1, Tablets 1-21. Occasional Publications of the Samuel Noah Kramer Fund, 17. Philadelphia: Samuel Noah Kramer Fund.

Freedman 2017 = S.M. Freedman. If the city is set on a height: The Akkadian Omen Series Šumma Alu in Mele Šakin. Volume 3: Tablets 41-63. Occasional Publications of the Samuel Noah Kramer Fund 20. Winona Lake: Eisenbrauns.

Gabbay $2016=$ U. Gabbay. The Exegetical Terminology of Akkadian Commentaries. Culture and History of the Ancient Near East 82. Leiden and Boston: Brill.

Gaspa $2007=$ S. Gaspa. Vessels in Neo-Assyrian documents: capacity measures and listing conventions. State Archives of Assyria Bulletin 16: 145-184.

Geller $1984=$ M.J. Geller. Review of Franz Köcher, Die babylonisch-assyrische Medizin in Texten und Untersuchungen, Bd. V und VI. Zeitschrift für Assyriologie und Vorderasiatische Archäologie 74: 292-297.

Geller $1985=$ M.J. Geller. Forerunners to Udug-hul: Sumerian Exorcistic Incantations. Freiburger altorientalische Studien 12. Stuttgart: Franz Steiner Verlag Wiesbaden.

Geller 1988 = M.J. Geller. New Duplicates to SBTU II. Archiv für Orientforschung 35: 1-23.

Geller 1991 = M.J. Geller. Akkadian Medicine in the Babylonian Talmud. In A Traditional Quest. Essays in Honor of Luis Jacobs, ed. D. Cohn-Sherbok. Sheffield: JSOT: 102-112.

Geller 2001/02 = M.J. Geller. West Meets East: Early Greek and Babylonian Diagnosis. Archiv für Orientforschung 48/49: 50-75.

Geller 2003 = M.J. Geller. Paranoia, the Evil Eye, and the Face of Evil. In Literatur, Politik und Recht in Mesopotamien. Festschrift für Claus Wilcke, eds. W. Sallaberger et al. Orientalia Biblica et Christiana 14. Wiesbaden: Harrassowitz: 115-134.

Geller $2005=$ M.J. Geller. Renal and Rectal Disease Texts. Die babylonisch-assyrische Medizin in Texten und Untersuchungen 7. Berlin: Walter de Gruyter.

Geller $2006=$ M.J. Geller. Les maladies et leurs causes, selon un texte médical paléobabylonien. Le Journal des Médecines Cunéiformes 8: 7-12.

Geller 2007a = M.J. Geller. Evil demons canonical Utukkū Lemnūtu incantations: introduction, cuneiform text, and transliteration with a translation and glossary. State Archives of Assyria Cuneiform Texts 5. Helsinki: Neo-Assyrian Text Corpus Project.

Geller 2007b = M.J. Geller. Textes médicaux du Louvre, nouvelle edition AO 11447, AO 7760 et AO 66774. Première partie. Le Journal des Médecines Cunéiformes 10: 4-18.

Geller 2007c = M.J. Geller. Incantations within Akkadian Medical Texts. In The Babylonian World, ed. G. Leick. New York and London: Taylor and Francis: 389-399.

Geller 2009 = M.J. Geller. Introduction to "Oeil malade et mauvais oeil". In Advances in Mesopotamian Medicine from Hammurabi to Hippocrates. Proceedings of the International Conference "Oeil malade et mauvais oeil," Collège de France, Paris, 23rd June 2006, eds. A. Attia and G. Buisson. Cuneiform Monographs 37. Leiden and Boston: Brill: 1-12.

Geller 2010a = M.J. Geller. Ancient Babylonian Medicine. Theory and Practice. Chichester: Wiley-Blackwell. 
Geller 2010b = M.J. Geller. Augenkrankheiten. Texte zur Heilkunde. Texte aus der Umwelt des Alten Testaments. Neu Folge 5: 61-63.

Geller $2011=$ M.J. Geller. Review of Maul and Strauss. 2011. Ritualbeschreibungen und Gebete I. Zeitschrift für Assyriologie und Vorderasiatische Archäologie 101: 339-344.

Geller 2014 = M.J. Geller. Melothesia in Babylonia Medicine, Magic, and Astrology in the Ancient Near East. Science, technology, and medicine in ancient cultures 2. Boston and Berlin: Walter de Gruyter.

Geller 2015a = M.J. Geller, Review of N. Heeßel, Divinatorische Texte II. Archiv für Orientforschung 53: 201-207.

Geller 2015b = M.J. Geller. Encyclopaedias and Commentaries. In In the Wake of the Compendia. Infrastructural Contexts and the Licensing of Empiricism in Ancient and Medieval Mesopotamia, ed. J.C. Johnson. Boston and Berlin: Walter de Gruyter: 31-45.

Geller 2015C = M.J. Geller. Review of Böck, B. 2014. The Healing Goddess Gula. Towards an Understanding of Ancient Babylonian Medicine. Archiv für Orientforschung 53: 160-163.

Geller $2016=$ M.J. Geller. Healing Magic and Evil Demons: Canonical Udug-hul Incantations. With the Assistance of Luděk Vacín. Die babylonisch-assyrische Medizin in Texten und Untersuchungen 8. Boston and Berlin. Walter de Gruyter.

George 2013 = A.R. George. Babylonian Divinatory Texts Chiefly in the Schøyen Collection. Cornell University studies in Assyriology and Sumerology 18. Bethesda: CDL Press.

George $2016=$ A.R. George. Mesopotamian Incantations and Related Texts in the Schøyen Collection. Manuscripts in the Schøyen collection. Cuneiform texts 8. Cornell University studies in Assyriology and Sumerology 32. Bethesda: CDL Press.

Goetze 1955 = A. Goetze. An Incantation against Diseases. Journal of Cuneiform Studies 9: 8-18.

Golder 2007 = W. Golder. Hippokrates und das Corpus Hippocraticum. Eine Einführung für Philologen und Mediziner. Würzburg: Königshausen and Neumann.

Goltz 1974 = D. Goltz. Studien zur altorientalischen und griechischen Heilkunde: Therapie-Arzneibereitung - Rezeptstruktur. Sudhoffs Archiv, Beihefte 16. Wiesbaden: Steiner.

Gottheil $1899=$ R. Gottheil. Contributions to Syriac Folk Medicine. Journal of the American Oriental Society 20: 186-205.

Gottstein and Panayotov $2014=$ N. Gottsteint and S.V. Panayotov. Cuneiform Spotlight of the Neo- and Middle Assyrian Signs. Dresden: Islet.

Graf 1997 = F. Graf. Magic in the Ancient World. Revealing antiquity 10. Cambridge: Harvard University Press.

Gurney $1953=$ O.R. Gurney. Further Texts from Dur-Kurigalzu. Sumer 9: 21-34.

Gurney and Hulin $1964=0$. R. Gurney and P. Hulin. The Sultantepe Tablets II. Occasional Publications of the British Institute of Archaeology at Ankara 7. London: British Institute of Archaeology at Ankara.

Haas and Thiel1978 = V. Haas and H.J. Thiel. Die Beschrörungsrituale der Allaiturab(h)i und verwandte Texte. Alter Orient und Altes Testament, Hurritologische Studien II. Neukirchen-Vluyn: Kevelaer, Butzon \& Bercker.

Hannen $2014=\mathrm{K}$. Hannen. Bearbeitung und Kontext des medizinischen Textes VAT13732. Freie wissenschaftliche Arbeit zur Erlangung eines Bachelorgrades am Fachbereich Geschichts- und Kulturwissenschaften der Freien Universität Berlin im Bachelorstudiengang Altorientalistik.

Hatfield $2004=$ G. Hatfield. Encyclopedia of Folk medicine: old world and new world traditions. Santa Barbara: ABC-CLIO Interactive.

Haussperger $2000=$ M. Haussperger. Einige medizinische Anmerkungen zum Text BAM 3. In Studi sul Vicino Oriente Antico dedicati alla memoria di Luigi Cagni, ed. S. Graziani. Napoli: Istituto universitario orientale: $439-450$. 
Heeßel $2000=$ N.P. Heeßel. Babylonisch-assyrische Diagnostik. Alter Orient und Altes Testament 43. Münster: Ugarit.

Heeßel 2001/02 = N.P. Heeßel. "Wenn ein Mann zum Haus des Kranken geht." Intertextuelle Bezüge zwischen der Serie šumma ālu und der zweiten Tafel der Series SA.GIG. Archiv für Orientforschung 48/49: 24-49.

Heeßel 2007 = N.P. Heeßel. The Hands of the Gods: Disease Names and Divine Anger. In Disease in Babylonia, eds. I.L. Finkel and M.J. Geller. Cuneiform Monographs 36. Leiden and Boston: Brill: 120-130.

Heeßel 2009 = N.P. Heeßel. The Babylonian Physician Rabâ-ša-Marduk. Another look at physicians and exorcists in the Ancient Near East. In Advances in Mesopotamian Medicine from Hammurabi to Hippocrates. Proceedings of the International Conference "Oeil malade et mauvais oeil," Collège de France, Paris, 23rd June 2006, eds. A. Attia and G. Buisson. Cuneiform Monographs 37. LeidenBoston: Brill: 13-28.

Heeßel 2010 = N.P. Heeßel. 2010. Erkrankungen des Kopfes. In Texte zur Heilkunde, eds. B. Janowski and D. Schwemer. Texte aus der Umwelt des Alten Testaments, Neue Folge 5. Gütersloh: Gütersloher Verlagshaus: 46-52.

Heeßel 2018 = N.P. Heeßel. Identifying Divine Agency: The Hands of the Gods in Context. In Sources of Evil, Studies in Mesopotamian Exorcistic Lore, eds. G. Van Buylaere, M. Luukko, D. Schwemer, A. Mertens-Wagschal. Ancient Magic and Divination 15. Leiden and Boston: Brill: 135-149.

Heeßel and Al-Rawi $2003=$ N.P. Heeßel and F.N.H. Al-Rawi. Tablets from the Sippar Library XII. A Medical Therapeutic Text. Iraq 65: 221-239.

Heiss, Stika, De Zorzi, Jursa 2012-2013 = A. G. Heiss, H.-P. Stika, N. De Zorzi, and M. Jursa. Nigella in the Mirror of Time: A Brief Attempt to Draw a Genus' Ethnohistorical Portrait. Offa 69/70: 147-169.

Herrero $1975=$ P. Herrero. Une tablette médicale assyrienne inédite. Revue d'Assyriologie 69: 41-53.

Hrůša $2010=$ I. Hrůša. Die akkadische Synonymenliste malku=šarru. Eine Textedition mit Übersetzung und Kommentrar. Alter Orient und Altes Testament 50. Münster: Ugarit.

Hoch $1994=$ J.E. Hoch. Semitic Words in Egyptian Texts of the New Kingdom and Third Intermediate Period. Princeton: Princeton University Press.

Hooper and Field $1937=$ D. Hooper and H. Field. Useful Plants and Drugs of Iran and Iraq. Botanical Series. Field Museum of Natural History 9/3. Chicago, Illinois: Field Museum of Natural History Chicago.

Hunger $1968=\mathrm{H}$. Hunger. Babylonische und Assyrische Kolophone. Alter Orient und Altes Testament 2. Neukirchen-Vluyn: Kevelaer, Butzon \& Bercker.

Hussein et al. $2016=$ M.M. Hussein, M. Altaweel, and Mc. Gibson. Nimrud: The Queens' Tombs. Baghdad; Chicago: Iraqi State Board of Antiquities and Heritage: Oriental Institute of the University of Chicago.

Jeyes 1989 = U. Jeyes. Old Babylonian Extispicy: Omen Texts in the British Museum. Uitgaven van het Nederlands Historisch-Archaeologisch Institut te Istanbul 64. Istanbul: Nederlands Historisch-Archaeologisch Instituut te İstanbul.

Johandi 2019 = A. Johandi. The God Asar / Asalluhi in the Early Mesopotamian Pantheon. Tartu: University of Tartu Press.

Jones 1998 = W.H.S. Jones. Volume IV: Nature of Man. Regimen in Health. Humours. Aphorisms. Regimen 1-3. Dreams. Loeb Classical Library 150. Cambridge, MA: Harvard University Press.

Jursa $2009=$ M. Jursa. Die Kralle des Meeres und andere Aromata. In Philologisches und Historisches zwischen Anatolien und Sokotra Analecta Semitica. In Memoriam Alexander Sima, eds. W. Arnold et al. Wiesbaden: Harrassowitz: 147-180.

Kämmerer 2000 = T. Kämmerer. Pathologische Veränderungen an Leber und Galle. Das Krankheitsbild der Gelbsucht. Revue d'Assyriologie et d'archéologie orientale 94: 57-93. 
Karahashi $2000=$ F. Karahashi. Sumerian Compound Verbs with Body-Part Terms. A Dissertation submitted to the Faculty of the Division of the Humanities in Candidacy for the Degree of Doctor of Philosophy: The Department of Near Easter Languages and Civilizations. Chicago, Illinois.

Kinnier Wilson 2005a $=$ J.V. Kinnier Wilson. Notes on the Assyrian Pharmaceutical Series URU.AN.NA : MAŠTAKAL. Journal of Near Eastern Studies 64: 45-51.

Kinnier Wilson 2005b $=$ J.V. Kinnier Wilson. On the Cryptogams in the lexical and related texts. Le Journal des Médecines Cunéiformes 6: 1-21.

Kinnier Wilson $2011=$ J.V. Kinnier Wilson. A Journey through the Prescriptions. Le Journal des Médecines Cunéiformes 17: 1-24.

Kleber 2016a = K. Kleber. Sekēru - "to purify", not "to gild". Nouvelles Assyriologiques Brèves et Utilitaires 2016/3: 98-99.

Kleber $2016 \mathrm{~b}=\mathrm{K}$. Kleber. On the ghost word tasniqtu "verification" and the stone called "beginning" in Hh. XVI, 189. Nouvelles Assyriologiques Brèves et Utilitaires 2016/4: 151.

Köcher 1963a = F. Köcher. Keilschrifttexte aus Assur 1. Die babylonisch-assyrische Medizin in Texten und Untersuchungen 1. Berlin: Walter de Gruyter.

Köcher 1963b = F. Köcher. Keilschrifttexte aus Assur 2. Die babylonisch-assyrische Medizin in Texten und Untersuchungen 2. Berlin: Walter de Gruyter.

Köcher, F. 1964. Keilschrifttexte aus Assur 3. Die babylonisch-assyrische Medizin in Texten und Untersuchungen 3. Berlin: Walter de Gruyter.

Köcher 1971 = F. Köcher. Keilschrifttexte aus Assur 4, Babylon, Nippur, Sippar, Uruk und unbekannter Herkunft. Die babylonisch-assyrische Medizin in Texten und Untersuchungen 4. Berlin: Walter de Gruyter.

Köcher 1980a = F. Köcher. Keilschrifttexte aus Niniveh 1. Die babylonisch-assyrische Medizin in Texten und Untersuchungen 5). Berlin and New York: Walter de Gruyter.

Köcher 1980b = F. Köcher. Keilschrifttexte aus Niniveh 2. Die babylonisch-assyrische Medizin in Texten und Untersuchungen 6. Berlin and New York: Walter de Gruyter.

Köcher 1995 = F. Köcher. Ein Text medizinischen Inhalts aus dem neubabylonischen Grab 405. In Uruk - Die Gräber, eds. R. M. Böhmer \& F. Pedde \& B. Salje. Ausgrabungen in Uruk-Warka Endberichte 10. Mainz: Philipp von Zabern: 203-217.

Köcher, Oppenheim and Güterbock 1957/58 = F. Köcher, F., A.L. Oppenheim, and H.G. Güterbock. The Old-Babylonian Omen Text VAT 7525. Archiv für Orientforschung 18: 62-80.

Krebernik $1984=$ M. Krebernik. Die Beschwörungen aus Fara und Ebla, Untersuchungen zur ältesten keilschriftlichen Beschwörungsliteratur. Texte und Studien zur Orientalistik 2. Hildesheim; Zürich: G. Olms.

Kwasman $2015=$ T. Kwasman. Loanwords in Jewish Babylonian Aramaic: Some Preliminary Observations. In The Archaeology and Material Culture of the Babylonian Talmud, ed. M. J. Geller. IJS Studies in Judaica 16. Leiden and Boston: Brill: 333-386.

Lambert 1957/58 = W.G. Lambert. Three Unpublished Fragments of the Tukulti-Ninurta Epic. Archiv für Orientforschung 18: 38-51.

Lambert $1965=$ W.G. Lambert. A Middle Assyrian Tablet of Incantations. In Studies in honor of Benno Landsberger on his seventy-fifth birthday, April 21, 1965, eds. H. G. Güterbock and T. Jacobsen. Assyriological studies 16. Chicago: University of Chicago Press: 283-288.

Lambert $2008=$ W.G. Lambert. The Classification of Incantations. In Proceedings of the 51st Rencontre Assyriologique Internationale held at The Oriental Insitute of The University of Chicago July 18-22, 2005 ; dedicated to the memory of Erica Reiner, eds. R.D. Biggs, J. Myers, and M.T. Roth. Series in Ancient Oriental Civilization 62. Chicago: The Oriental Institute of the University of Chicago: 9397.

Lambert $2013=$ W.G. Lambert. Babylonian Creation Myths. Mesopotamian Civilizations 16. Winona Lake: Eisenbrauns. 
Lambert and Millard $1968=$ W.G. Lambert and A.R. Millard. Catalogue of the Cuneiform Tablets in the Kouyunjik Collection of the British Museum: Second Supplement. London: Trustees of the British Museum.

Landsberger 1934 = B. Landsberger. Die Fauna des Alten Mesopotamien nach der 14. Tafel der Series Har-ra $=$ Hubullu. Abhandlungen der Philologisch-historischen Klasse der Sächsischen Akademie der Wissenschaften 42. Leipzig. S. Hirzel.

Landsberger $1958=$ B. Landsberger. Corrections to the Article an Old Babylonian Charm against Merhu . Journal of Near Eastern Studies 17: 56-58.

Landsberger $1967=\mathrm{B}$. Landsberger. The Date Palm and its By-products according to the Cuneiform Sources. Archiv für Orientforschung, Beiheft 17. Graz: Selbstverlag des Herausgebers.

Landsberger and Jacobsen 1955 = B. Landsberger and T. Jacobsen. An Old Babylonian Charm against Merhu. Journal of Near Eastern Studies 14: 14-21.

Langholf $1990=$ V. Langholf. Medical Theories in Hippocrates. Berlin: Walter de Gruyter.

Leichty $1970=$ E. Leichty. The Omen Series Šumma Izbu. Texts from Cuneiform Sources 4. Locust Valley, New York: J. J. Augustin.

Leichty 1986 = E. Leichty. Catalogue of the Babylonian tablets in the British Museum 6, Tablets from Sippar, 1. London, British Museum Press.

Löw 1924/26 = I. Löw. Die Flora der Jüden. Wien: R. Loewit Verlag.

Maul 1994 = S.M. Maul. Zukunftsbewältigung. Eine Untersuchung altorientalischen Denkens anhand der babylonisch-assyrischen Löserituale (Namburbi). Baghdader Forschungen 18. Mainz: Philipp von Zabern.

Maul 2009 = S.M. Maul. Die Lesung der Rubra DÙ.DÙ.BI und KİD.KÌD.BI. Orientalia Nova Series 78. 6980.

Maul 2013 = S.M. Maul. Ein altorientalischer Pferdesegen - Seuchenprophylaxe in der assyrischen Armee. Zeitschrift für Assyriologie und Vorderasiatische Archäologie 103: 16-37.

Maul and Strauß $2011=$ S.M. Maul and R. Strauß. Ritualbeschreibungen und Gebete I. Mit Beiträgen von D. Schwemer. Keilschrifttexte aus Assur literarischen Inhalts 4. Wiesbaden: Harrassowitz.

Mayer 2005 = W.R. Mayer. Lexikalische Listen aus Ebla und Uruk. Orientalia Nova Series 74: 157-164. Mayer 2016 =W.R. Mayer. Zum akkadischen Wörterbuch: A-L. Orientalia Nova Series 85: 181-235.

Middeke-Conlin $2014=$ R. Middeke-Conlin. The Scents of Larsa: A Study of the Aromatics Industry in an Old Babylonian Kingdom. Cuneiform Digital Library Journal 2014.

Militarev and Kogan $2000=$ A. Militarev and L. Kogan. Semitic Etymological Dictionary. Vol I. Anatomy of Man and Animals. Alter Orient und Altes Testament 278/1. Münster: Ugarit.

Miller $2003=$ S.S. Miller. Some Observations on Stone Vessel Finds and Ritual Purity in Light of Talmudic Sources. In Zeichen aus Text und Stein: Studien aufdem Weg zu einer Archäologie des Neuen Testaments, eds. S Alkier and J. Zangenberg. Texte und Arbeiten zum neutestamentlichen Zeitalter 42. Tübingen: Francke: 402-419.

Müller-Kessler 1999 = C. Müller-Kessler. Dämon + YTB'L - Ein Krankheitsdämon. Eine Studie zu aramäischen Beschwörungen medizinischen Inhalts. In Munuscula Mesopotamica. Festschrift für Johannes Renger, ed. B. Böck et al. Alter Orient und Altes Testament 267. Münster: Ugarit: 341-354.

Nougayrol $1968=$ J. Nougayrol. Textes suméro-accadiens des Archives et Bibliothèques Privées D'Ugarit. Ugaritica 5: 1-446.

Nutton $2004=$ V. Nutton. Ancient Medicine. London and New York: Routledge.

Osbaldeston and Wood $2000=$ T.A. Osbaldeston and R.P.A. Wood. De materia medica: Being an herbal with many other medicinal materials: written in Greek in the first century of the common era: a new indexed version in modern English. Johannesburg: IBIDIS.

Oshima $2014=$ T. Oshima. Babylonian Poems of pious sufferers: Ludlul Bēl Nèmeqi and the Babylonian Theodicy. Tübingen: Mohr Siebeck. 
Panayotov $2013=$ S.V. Panayotov. A Ritual for a Flourishing Bordello. Bibliotheca Orientalis 70: 285309.

Panayotov $2015=$ S.V. Panayotov. 2015. The Gottstein System Implemented on a Digital Middle and Neo-Assyrian Palaeography. Cuneiform Digital Library Notes 2015/17.

Panayotov 2016a $=$ S.V. Panayotov. Fragments of the Nineveh Medical Composition IGI join UGU. Le Journal des Médecines Cunéiformes 27: 59-67.

Panayotov 2016b = S.V. Panayotov. Addenda and Corrigenda to "Fragments of the Nineveh Medical Composition IGI join UGU, JMC 27. Le Journal des Médecines Cunéiformes 28: 66-67.

Panayotov 2017 = S.V. Panayotov. Eye Metaphors, Analogies and Similes within Mesopotamian Magico-Medical Texts. In The Comparable Body. Analogy and Metaphor in Ancient Mesopotamian, Egyptian, and Greco-Roman Medicine, ed. J.Z. Wee. Studies in Ancient Medicine 49. Leiden-Boston: Brill: 204-246.

Panayotov 2018a = S.V. Panayotov. Notes on the Assur Medical Catalogue with Comparison to the Nineveh Medical Encyclopaedia. In Assyrian and Babylonian Scholarly Text Catalogues: Medicine, Magic and Divination, ed. U. Steinert. Die babylonisch-assyrische Medizin in Texten und Untersuchungen 9. Berlin and Boston: Walter de Gruyter: 88-118.

Panayotov 2018b = S.V. Panayotov. Magico-Medical Plants and Incantations on Assyrian House Amulets. In In Sources of Evil, Studies in Mesopotamian Exorcistic Lore, eds. G. Van Buylaere, M. Luukko, D. Schwemer, A. Mertens-Wagschal. Ancient Magic and Divination 15. Leiden and Boston: Brill: 192-222.

Pappi 2008 = C. Pappi. Salbe, Salbengefäß (ointment, ointment container). Reallexikon der Assyriologie und Vorderasiatischen Archäologie 11: 572-574.

Parpola 1983 = S. Parpola. Letters from Assyrian Scholars to the Kings Esarhaddon and Assurbanipal. Part II: Commentary and Appendices. Neukirchen-Vluyn: Kevelaer: Butzon \& Bercker.

Parpola 1993 = S. Parpola. Letters from Assyrian and Babylonian scholars. State archives of Assyria 10. Helsinki: Helsinki University Press.

Parys $2014=$ M. Parys. Édition d'un texte médical thérapeutique retrouvé à Assur (BAM 159). Le journal des médecines cunéiformes 23: 1-88.

Pedersén $1985=0$. Pedersén. Archives and Libraries in the City of Assur. A Survey of the Material from the German Excavations: Part I. Acta Universitatis Upsaliensis. Studia Semitica Upsaliensia 6. Uppsala: Almqvist och Wiksell.

Pommerening $2015=$ T. Pommerening. Milch einer Frau, die einen Knaben geboren hat. In Proceedings of the Tenth International Congress of Egyptologists, University of Aegean, Rhodes, 22-29 May 2008, Vol. II. eds. P. Kousoulis and N. Lazaridis. Leuven,Paris and Bristol, CT: Peeters: 20832095.

Postgate and Collon $1999=$ J.N. Postgate and D. Collon. More stray Assur tablets. State Archives of Assyria Bulletin 13: 1-16.

Potter $2010=$ P. Potter, Hippocrates, Volume IX. Coan Prenotions. Anatomical and Minor Clinical Writings. Loeb Classical Library 509. Cambridge, MA: Harvard University Press.

Potts et al. 1996 = D.T. Potts, et al. 1996. Guhlu and Guggulu. In Festschrift für Hans Hirsch zum 65. Geburtstag gewidmet von seinen Freunden, Kollegen und Schüllern, eds. A.A. Ambros and M. Köhbach. Wiener Zeitschrift für die Kunde des Morgenlandes 86. Wien: Institute für Orientalistik: 291305.

Radner $2014=$ K. Radner. Zagros Spice Mills: The Simurrean and the Hašimur Grindstones. In From Source to History: Studies on Ancient Near Eastern Worlds and Beyond Dedicated to Giovanni Battista Lanfranchi on the Occasion of His 65th Birthday on June 23, 2014, eds. S. Gaspa et al. Alter Orient und Altes Testament 412. Münster: Ugarit: 573-580. 
Radner $2016=$ K. Radner. Die beiden neuassyrischen Privatarchive. In Ausgrabungen in Assur: Wohnquartiere in der Weststadt, Teil I, eds. P.A. Miglus, K, Radner, and F.M. Stępniowski. Wiesbaden: Harrassowitz: 79-132, pls. 93-106.

Reade $1986=$ J.E. Reade. Archaeology and the Kuyunjik Archives. In Cuneiform Archives and Libraries: Papers read at the $30^{e}$ Rencontre Assyriologique Internationale, Leiden, 4-8 July 1983, ed. K.R. Veenhof. Uitgaven van het Nederlands Historisch-Archaeologisch Instituut te Istanbul 52. Istanbul: Nederlands Historisch-Archaeologisch Instituut te Istanbul: 213-222.

Reade $2016=$ J.E. Reade. The Gates of Nineveh. State Archives of Assyria Bulletin 22: 39-93.

Reiner 1995 = E. Reiner. Astral Magic in Babylonia. Transactions of the American Philosophical Society, New Series 85/4. Philadelphia. American philosophical Society.

Rendu Loisel 2016 = A.C. Rendu Loisel. Les Chants du monde: La paysage sonore de l'ancienne Mésopotamie. Toulouse: Presses Universitaires du Mirail.

Riddle $1985=$ J.M. Riddle. Dioscorides on Pharmacy and Medicine. History of science series 3. Austin: University of Texas Press.

Ritner $2000=$ R.K. Ritner. Innovations and Adaptations in Ancient Egyptian Medicine. Journal of Near Eastern Studies 59: 107-117.

Rochberg 2016 = F. Rochberg. Before Nature: Cuneiform Knowledge and the History of Science. Chicago: The University of Chicago Press.

Rölling 1993 = W. Rölling. Muschel. Reallexikon der Assyriologie und Vorderasiatischen Archäologie 8: 450-451.

Rosner 1995 = F. Rosner. Medicine in the Bible and the Talmud: Selections from Classical Jewish Sources. Library of Jewish law and ethics 5. Hoboken: KTAV Pub. House; Yeshiva University Press. Rudik $2011=$ N. Rudik. Die Entwicklung der keilschriftlichen sumerischen Beschwörungsliteratur von den Anfängen bis zur Ur III-Zeit. Dissertation zur Erlangung des akademischen Grades Doctor philosophiae (Dr. phil.) vorgelegt dem Rat der Philosophischen Fakultät der Friedrich-Schiller-Universität Jena. Accessible at academia.edu.

Rumor $2015=$ M. Rumor. Babylonian Pharmacology in Graeco-Roman Dreckapotheke. With an Edition of Uruanna III 1-143 (138). Zur Erlangung des Doktorgrades eingereicht am Fachbereich Geschichts- und Kulturwissenschaften der Freien Universität Berlin im Juli 2015.

Rumor $2018=$ M. Rumor. At the Dawn of Plant Taxonomy: Shared Structural Design of Herbal Descriptions in Šammu šikinšu and Theophrastus' Historia plantarum IX. In Mesopotamian Medicine and Magic. Studies in Honor of Markham J. Geller, ed. S.V. Panayotov and L. Vacín, with the assistance of Gene Trabich. Ancient Magic and Divination 14. Leiden and Boston: Brill: 446-461.

Rumor, in press $=M$. Rumor. The Identification of Sikillu as $\Sigma$ Kí $\lambda \lambda \alpha$ through its Descriptions and Uses in Mesopotamian and Graeco-Roman Sources. In Proceedings of the Workshop held at the 61st Rencontre Assyriologique Internationale. Edited by J. C. Johnson. Winona Lake: Eisenbrauns.

Sallaberger 1996 = W. Sallaberger. Der babylonische Töpfer und seine Gefäße nach Urkunden altsumerischer bis altbabylonischer Zeit sowie lexikalischen und literarischen Zeugnissen. Mit einem Beitrag von M. Civil: HAR-ra = hubullu: Tablet $X$ dug = karpatu. Mesopotamian History and Environment, ser. 2, memoirs 3. Ghent: University of Ghent.

Salvini $2008=$ M. Salvini. Spigolature dai documenti cuneiformi di Tell Barri 'freddo, gelo, ghiaccio, uri, elefanti, leoni.' La parola del Passato 63: 76-101.

Scheil 1921 = V. Scheil. Catalogue de la collection Eugène Tisserant. Revue d'Assyriologie et d'archéologie orientale 18: 1-33.

Schmidtchen 2018 = E. Schmidtchen. Mesopotamische Diagnostik. Die diagnostisch-prognostische Standardserie Sakikkû als ein Kernbereich des Beschwörungsexperten sowie eine Neuedition des zweiten Kapitels. PhD, Freie Universität, Berlin.

Schramm 2001 =W. Schramm. Bann, Bann! Eine sumerisch-akkadische Beschwörungsserie. Göttinger Arbeitshefte zur altorientalischen Literatur 2. Göttingen: Seminar für Keilschriftforschung. 
Schramm 2008 = W. Schramm. Ein Compendium sumerisch-akkadischer Beschwörungen. Göttinger Beiträge zum Alten Orient 2. Göttingen: Universitätsverlag Göttingen.

Schuster-Brandis $2008=$ A. Schuster-Brandis. Steine als Schutz- und Heilmittel. Untersuchung zu ihrer Verwendung in der Beschwörungskunst Mesopotamiens im 1. Jt. v. Chr. Alter Orient und Altes Testament 46. Münster: Ugarit.

Schuster-Brandis 2012 = A. Schuster-Brandis. Stibium (Antimon). Reallexikon der Assyriologie und Vorderasiatischen Archäologie 13: 177-178.

Schwemer 1998 = D. Schwemer. Akkadische Rituale aus Hattuša. Die Sammeltafel KBO XXXVI 29 und verwandte Fragmente. Texte der Hethiter 23. Heidelberg: Winter.

Schwemer $2001=$ D. Schwemer. Die Wettergottgestalten Mesopotamiens und Nordsyriens im Zeitalter der Keilschriftkulturen. Materialien und Studien nach den schriftlichen Quellen. Wiesbaden: Harrassowitz.

Schwemer 2005/06 = D. Schwemer. Lehnbeziehungen zwischen dem Hethitischen und dem Akkadischen. Archiv für Orientforschung 51: 220-234.

Schwemer 2007 = D. Schwemer. Rituale und Beschwörungen gegen Schadenzauber. Keilschrifttexte aus Assur literarischen Inhalts 2. Wiesbaden: Harrassowitz.

Schwemer 2013 = D. Schwemer. Gauging the Influence of Babylonian magic: The reception of Mesopotamian tradition in Hittite ritual practice. In Diversity and standardization: perspectives on social and political norms in the Ancient Near East, eds. E. C. Cancik-Kirschbaum et al. Berlin: Akademie Verlag: $145-171$.

Schwemer 2018 = D. Schwemer. Evil Helpers: Instrumentalizing Agents of Evil in Anti-witchcraft Rituals. In Sources of Evil, Studies in Mesopotamian Exorcistic Lore, eds. G. Van Buylaere, M. Luukko, D. Schwemer, A. Mertens-Wagschal. Ancient Magic and Divination 15. Leiden and Boston: Brill: 173-191.

Scurlock $2006=$ J. Scurlock. Magico-Medical Means of Treating Ghost-Induced Illnesses in Ancient Mesopotamia Ancient Magic and Divination 3. Leiden and Boston: Brill.

Scurlock 2008a $=$ J. Scurlock. On some Terms for Leatherworking in Ancient Mesopotamia. In Proceedings of the 51st Rencontre Assyriologique Internationale held at The Oriental Insitute of The University of Chicago July 18-22, 2005 ; dedicated to the memory of Erica Reiner, eds. R.D. Biggs, J. Myers, and M.T. Roth. Series in Ancient Oriental Civilization 62. Chicago: The Oriental Institute of the University of Chicago: 171-176.

Scurlock 2008b = J. Scurlock. Some Mesopotamian Medicine for a Greek Headache. In Studies in Ancient Near Eastern World View and Society presented to Marten Stol on the occasion of his 65th birthday, 10 November 2005, and his retirement from the Vrije Universiteit Amsterdam, ed. R. J. van der Spek et al. Bethesda: CDL Press: 195-202.

Scurlock $2014=$ J. Scurlock. Sourcebook for Ancient Mesopotamian Medicine. Writings from the Ancient World 36. Atlanta, Georgia: Society of Biblical Literature.

Scurlock 2017 = J. Scurlock. Medical Texts. In The Context of Scripture 4. Supplements, ed. K. L. Younger Jr. Leiden and Bosto: Brill: 275-312.

Scurlock and Andersen $2005=$ J. Scurlock and B.R. Andersen. Diagnoses in Assyrian and Babylonian Medicine. Ancient Sources, Translations, and Modern Medical Analyses. Urbana: University of Illinois Press.

Searight, Reade, and Finkel $2008=$ A. Searight, J. Reade, and I.L. Finkel. Assyrian Stone vessels and related material in the British Museum. Oxford: Oxbow Books.

Spencer 1989 = W.G. Spencer. De medicina by Aulus Cornelius Celsus. Loeb classical library 304. London: Heinemann.

Stadhouders $2011=$ H. Stadhouders. The Pharmacopoeial Handbook Šammu šikinšu - An Edition. Le Journal des Médecines Cunéiformes 18: 3-50. 
Stadhouders $2012=$ H. Stadhouders. The Pharmacopoeial Handbook Šammu šikinšu - A Translation. Le Journal des Médecines Cunéiformes 19: 1-21.

Stadhouders $2018=$ H. Stadhouders. The mirišmarû-Plant: Orthographic Novelties and a Consecratory Spell. Die Welt des Orients 48: 116-127.

Steinert $2015=$ U. Steinert. "Tested" Remedies in Mesopotamian Medical Texts: A Label for Efficacy Based on Empirical Observation? In In the Wake of the Compendia. Infrastructural Contexts and the Licensing of Empiricism in Ancient and Medieval Mesopotamia, ed. J. C. Johnson. Boston and Berlin: Walter de Gruyter: 103-145.

Steinert, Panayotov, Geller, Schmidtchen and Johnson 2018 = U. Steinert, S.V. Panayotov, M.J. Geller, E. Schmidtchen, and J.C. Johnson. AMC Text Edition. In Assyrian and Babylonian Scholarly Text Catalogues: Medicine, Magic and Divination, ed. U. Steinert. Die babylonisch-assyrische Medizin in Texten und Untersuchungen 9. Boston and Berlin: Walter de Gruyter: 209-219.

Sternitzke $2012=$ K. Sternitzke. Spatel, Sonde und Skalpell. Medizinische Instrumente im Archäologischen Befund. In Stories of long ago. Festschrift für Michael D. Roaf, eds. H. Baker, K. Kaniuth und A. Otto. Alter Orient und Altes Testament 397. Münster: Ugarit: 649-666.

Stol $1979 \mathrm{a}=\mathrm{M}$. Stol. On Trees, mountains and millstones in the ancient Near East. With a chapter by $\mathrm{K}$. van Lerberghe. Mededelingen en verhandelingen van het Vooraziatisch-egyptisch Genootschap "Ex Oriente Lux" 21. Leiden: Ex oriente lux.

Stol 1979a $=$ M. Stol. Review of Early Old Babylonian Documents by Stephen D. Simmons. Journal of Cuneiform Studies 31: 177-183.

Stol $1985=$ M. Stol. The Cucurbitaceae in Cuneiform Texts. Bulletin of Sumerian Agriculture 3: 81-92.

Stol $1986=$ M. Stol. Blindness and Night-Blindness in Akkadian. Journal of Near Eastern Studies 45: 295-299.

Stol 1989a $=$ M. Stol. Old Babylonian Ophthalmology. In Reflets des deux fleuves: volume de mélanges offerts à André Finet, eds. M. Lebeau and P. Talon. Akkadica Supplementum 6. Leuven: Peeters: 163-166.

Stol 1989b = M. Stol. Malz. Reallexikon der Assyriologie und Vorderasiatischen Archäologie 7: 322329.

Stol 1991/92 = M. Stol. Diagnosis and Therapy in Babylonian medicine. Jaarbericht Ex Oriente Lux 32: 42-65.

Stol 1993a $=$ M. Stol. Epilepsy in Babylonia. Cuneiform Monographs 2. Groningen: Styx.

Stol 1993b $=$ M. Stol. Milk, Butter, and cheese. Bulletin on Sumerian Agriculture 7: 99-113.

Stol $1994=$ M. Stol. Beer in Neo-Babylonian Times. In Drinking in Ancient Societies: History and Culture of Drinks in the Ancient Near East: Papers of a Symposium Held in Rome, May 17-19, 1990, ed. L. Milano. History of the Ancient Near East, Studies 6. Padova: Sargon: 155-183.

Stol $1998=$ M. Stol. Einige kurze Wortstudien. In Festschrift für Rykle Borger zu seinem 65. Geburtstag am 24. Mai 1994: tikip santakki mala bašmu, ed. S. Maul. Cuneiform Monographs 10. Groningen: Styx Publications: $343-352$.

Stol 2007a = M. Stol. Fevers in Babylonia In Disease in Babylonia, eds. I. L. Finkel and M. J. Geller. Cuneiform Monographs 36. Leiden and Boston: Brill: 1-39.

Stol 2007b $=$ M. Stol. Remarks on some Sumerograms and Akkadian. In From the workshop of the Chicago Assyrian Dictionary, volume 2: Studies presented to Robert D. Biggs, June 4, 2004, eds. M.T. Roth, et al. Chicago: The Oriental Institute: 233-242.

Stol $2012=$ M. Stol. Bitumen in Ancient Mesopotamia. The Textual Evidence. Bibliotheca Orientalis 69: 48-60.

Stol $2014=$ M. Stol. Trüffel. Reallexikon der Assyriologie und Vorderasiatischen Archäologie 14: 149150.

Stol 2016a $=$ M. Stol. Review of Borger, R. Mesopotamisches Zeichenlexikon. Zweite, revidierte und aktualisierte Auflage. Orientalistische Literaturzeitung 111: 119-134. 
Stol 2016b = M. Stol. Women in the Ancient Near East. Boston and Berlin: Walter de Gruyter.

Stol, Cadelli, and Milano $2001=$ M. Stol, D. Cadelli, D. and L. Milano. Vicino Oriente antico. La cura del corpo, in Storia della Scienza, <http://www.treccani.it/enciclopedia/vicino-oriente-antico-la-curadel-corpo_\%28Storia_della_Scienza\%29/>.

Tecusan $2004=$ M. Tecusan. The Fragments of the Methodists, Methodism outside Soranus. Leiden and Boston: Brill.

Thompson $1923=$ R.C. Thompson. Assyrian Medical Texts from the Originals in the British Museum. London et. al.: AMS Pr.

Thompson 1924 = R.C. Thompson. Assyrian Medical Texts. Proceedings of the Royal Society of Medicine 17: $1-34$.

Thompson $1926=$ R.C. Thompson. Assyrian Medical Texts II. Proceedings of the Royal Society of Medicine 19 (Section of the history of Medicine): 29-78.

Thompson 1937a = R.C. Thompson. Assyrian Prescriptions for the Head. The American Journal of Semitic Languages and Literatures 53: 217-238.

Thompson 1937b = R.C. Thompson. Assyrian Prescriptions for the Head (Concluded). The American Journal of Semitic Languages and Literatures 54: 12-40.

Thompson 1949 = R.C. Thompson. A Dictionary of Assyrian Botany. London: The British Academy.

Townsend and Guest $1980=$ C.C. Townsend and E. Guest. (eds.). Cornaceae to Rubiaceae. Flora of Iraq 4/1. Baghdad.

Van Dijk 1983 = J.J.A. van Dijk. Lugal ud me-lám-bi Nir-gál: le récit épique et didactique des Travaux de Ninurta, du Déluge et de la Nouvelle Création: texte, traduction et introduction. Leiden: Brill.

Van Dijk and Geller $2003=$ J.J.A. van Dijk and M.J. Geller. Ur III Incantations from the Frau Professor Hilprecht-Collection, Jena. Texte und Materialien der Frau Professor Hilprecht Collection of Babylonian Antiquities im Eigentum der Universität Jena, Bd. 6. Wiesbaden: Harrassowitz.

Viano 2016 = M. Viano. The Reception of Sumerian Literature in the Western Periphery. Antichistica: Studi Orientali 9/4. Venezia: Edizioni Ca’ Foscari.

Vodenicharov and Petrov 2001: Otrovni rastenija i otravjanija s tjah (Воденичаров, Д.Г. и А. Петров. Отровни растения и отравяния с тях). Sofia: Pensoft.

von Soden 1971 = W. von Soden. Der große Hymnus an Nabû. Zeitschrift für Assyriologie und Vorderasiatische Archäologie 61: 44-71.

von Soden 1995 = W. von Soden. Grundriss der akkadischen Grammatik. 3., ergänzte Auflage unter Mitarbeit von Werner R. Mayer. Roma: Pontificium Inst. Biblicum.

von Weiher 1983 = E. von Weiher. Spätbabylonische Texte aus Uruk, Teil 2. Ausgrabungen der Deutschen Forschungsgemeinschaft in Uruk-Warka 10. Berlin: Gebr. Mann Verlag.

von Weiher 1988 = E. von Weiher. Spätbabylonische Texte aus Uruk, Teil 3. Ausgrabungen der Deutschen Forschungsgemeinschaft in Uruk-Warka 12. Berlin: Gebr. Mann Verlag.

Wang and Carey $2014=$ D.Q-H. Wang and M.C. Carey. Therapeutic Uses of animal biles in traditional Chinese medicine: An ethnopharmacological, biophysical chemical and medicinal review. World Journal of Gastroenterology 20. 9952-9975.

Wasserman $2007=$ N. Wasserman. Between Magic and Medicine - Apropos of an Old Babylonian Therapeutic Text against the Kurārum Disease. In Disease in Babylonia, eds. I. L. Finkel and M. J. Geller. Cuneiform Monographs 36. Leiden and Boston: Brill: 40-61.

Wasserman $2010=$ N. Wasserman. From the Notebook of a Professional Exorcist. In Von Göttern und Menschen: Beiträge zu Literatur und Geschichte des Alten Orients. Festschrift für Brigitte Groneberg, eds. D. Shehata, F. Weiershäuser, and K. Zand. Cuneiform Monographs 41. Leiden-Boston: Brill: 329-349.

Wasserman $2015=$ N. Wasserman. Piercing the Eyes: an Old Babylonian love incantation and the preparation of kohl. Bibliotheca Orientalis 72: 601-612. 
Weeden $2009=$ M. Weeden. The Akkadian Words for "Grain" and the God Haya. Die Welt des Orients 39: 77-107.

Westendorf $1999=$ W. Westendorf. Handbuch der altägyptischen Medizin 1. und 2. Band. Handbuch der Orientalistik 36. Leiden: Brill.

Westenholz $2010=$ J.G. Westenholz. Ninkarrak - an Akkadian goddess in Sumerian guise. In Von Göttern und Menschen: Beiträge zu Literatur und Geschichte des Alten Orients. Festschrift für Brigitte Groneberg, eds. D. Shehata, F. Weiershäuser, and K. Zand. Cuneiform Monographs 41. LeidenBoston: Brill: 377-405

Westenholz and Sigrist $2006=$ J.G. Westenholz and M. Sigrist. The Brain, the Marrow and the Seat of Cognition in Mesopotamian Tradition. Le Journal des Médecines Cunéiformes 7: 1-10.

Wiggermann 1992 = F.A.M. Wiggermann. Mesopotamian Protective Spirits: The Ritual Texts. Cuneiform Monographs 1. Groningen: Styx.

Wiggermann $2000=$ F.A.M. Wiggermann. 'Lamaštu, Daughter of Anu. A Profile.' In Birth in Babylonia and the Bible. Its Mediterranean Setting, M. Stol. Cuneiform Monographs 14. Groningen: Styx: $217-52$.

Wiseman and Black 1996 = D.J. Wiseman and J.A. Black. 1996. Literary Texts from the Temple of Nabû. Cuneiform Texts from Nimrud 4. Oxford: British School of Archaeology in Iraq.

Worthington $2005=$ M. Worthington. Edition of UGU 1 (=BAM 480 etc.). Le Journal des Médecines Cunéiformes 5: 6-43.

Worthington $2006=$ M. Worthington. Edition of BAM 3. Le Journal des Médecines Cunéiformes 7. 18 48.

Worthington $2007=$ M. Worthington. Addenda and Corrigenda to "Edition of UGU 1 (=BAM 480 etc.)" and "Edition of BAM 3". Le Journal des Médecines Cunéiformes 9: 43-48.

Zaccagnini $1983=\mathrm{C}$. Zaccagnini. Patterns of Mobility among Ancient near Eastern Craftsmen. Journal of Near Eastern Studies 42: 245-264.

Ziegler $2005=$ N. Ziegler. Les vaisseaux sanguins et Enûma eliš VI: 5. Le Journal des Médecines Cunéiformes 5: 4-5.

Zomer 2015 = E. Zomer. Review of Böck. 2014. The Healing Goddess Gula. Towards an Understanding of Ancient Babylonian Medicine. Bibliotheca Orientalis 72: 106-110.

Zomer 2018 = E. Zomer. 'The Physician is the Judge!'- A Remarkable Divine Dialogue in the Incantation: ÉN ur-saĝ dasal-lú-ḩi igi-bé hée-pà saĝ-hul-bga-za hé-pà. Le Journal des Médecines Cunéiformes 31: 38-42. 